L. Petrov ${ }^{1}$, PhD, Assoc. Prof., T. Borisenko ${ }^{2}$

${ }^{1}$ Military Academy, 10 Fountain road Str., Odesa, Ukraine, 65009

${ }^{2}$ LLC “Telecard-Pribor”, Heavenly Hundred Ave., 105, Odesa, Ukraine, 65104; e mail: borisenko.taras@gmail.com

\title{
APPLICATION OF ELEMENTS OF THE THEORY OF UNACCOUNTED CORIOLIS FORCES IN THE PROCESS OF ROLLING A WHEELED PROPELLER
}

\begin{abstract}
Л.М. Петров, Т.М. Борисенко. Застосування елементів теорії неврахованих сил Кориоліса у процесі кочення колісного рушія. Робочий процес кочення колісного рушія супроводжується стисканням та розтягуванням шини при іiі деформації. Для підвищення працездатності мобільних енергетичних засобів, велика увага приділяється проблемі збільшення ККД колісних рушіїв, яка передбачена Законом України "Про систему інженерно-технічного забезпечення агропромислового комплексу України". Розвиток порушеної проблеми буде спрямований на підвищення ККД колісного рушія шляхом удосконалення його конструкції. Врахування сил Кориоліса дозволить конструкторам удосконалити конструкцію протектора автомобільного колеса, що в свою чергу підвищить надійність керування тягово-транспортним засобом тим самим буде збільшена вірогідність безпечності його руху. В статті розглянуті питання впливу Кориолісової сили на динаміку руху колісного рушія. Метою дослідження є удосконалення технології кочення колісного рушія, перетворення енергії підведеної до колісного рушія в Кориолісову силу, яка $є$ допоміжним фактором до цієї технології. Наукова та практична значущості роботи полягає в тому, що вперше запропонована технологія в якій врахована частка енергії, яка відповідає за безпеку руху і підведена до колісного рушія під назвою Кориолісова сила. Методологією дослідження являлося встановити математичний зв'язок Кориолісової сили з динамікою кочення колісного рушія. Результатом $\epsilon$ розроблена геометрія роботи колісного рушія у циклі демпфування провалу опорної поверхні, виявлені негативні наслідки дії Кориолісової сили на безпеку руху транспортного засобу. Цінність проведеного дослідження, результати проведеної роботи дозволять зробити внесок в галузь автомобільного виробництва. Запропоновано модель для підвищення безпеки руху транспортного засобу.

Ключові слова: фізико-математична модель, рушій, колесо, Кориолісова сила фізико-математична модель, рушій, колесо, Кориолісова сила

L. Petrov, T. Borisenko. Application of elements of the theory of unaccounted Coriolis forces in the process of rolling a wheeled propeller. The working process of rolling the wheel propulsion is accompanied by compression and extension of the tire during its deformation. To improve the operability of mobile energy, much attention is paid to the problem of increasing the efficiency of wheeled propellers, provided for by the Law of Ukraine "On the system of engineering and technical support for the agricultural sector of Ukraine" The development of the problem will be aimed at increasing the efficiency of the wheel propulsion by improving its design. Consideration of Coriolis forces will allow designers to improve the design of the tread of a car wheel, which in turn will increase the reliability of driving a towing vehicle, thereby increasing the likelihood of its safety. The article considers the influence of the Coriolis force on the dynamics of the movement of wheel propulsion. The aim of the study is to improve the technology of rolling the wheel propulsion, the conversion of energy supplied to the wheel propulsion into the Coriolis force, which is an auxiliary factor in this technology. The scientific and practical significance of the work lies in the fact that for the first time a technology is proposed which takes into account the fraction of energy that is responsible for the safety of movement and is brought to wheel propulsion called Coriolis force. The research methodology was to establish the mathematical relationship of the Coriolis force with the rolling dynamics of the wheel propulsion. The result is the developed geometry of the wheel mover in the damping cycle of the failure of the supporting surface, the negative consequences of the Coriolis force on the safety of the vehicle are revealed. The value of the study, the results of this work will make it possible to contribute to the automotive industry. A model is proposed to increase vehicle safety.

Keywords: physical-mathematical model, propulsion, wheel, Coriolis force
\end{abstract}

\section{Introduction}

Vehicle development extends the nomenclature of wheel drive designs on pneumatic tires and stimulates the intensification of research and development work aimed at better meeting operational requirements, reducing weight and improving the technology of wheel torque implementation.

The peculiarity of the working process of the wheel drive of the vehicle is the volatility of its dimensions, which is caused by the elastic deformation of the pneumatic tire when it interacts with the support surface. The degree of resizing depends on the elastic properties of the tire. This characteristic is of great theoretical and practical importance, as it directly enters into the equation of oscillation of

DOI: 10.15276/opu.2.58.2019.02

(C) 2019 The Authors. This is an open access article under the CC BY license (http://creativecommons.org/licenses/by/4.0/). 
the dynamic system road-wheel-machine and is used in solving the problem of improving the quality of rolling wheel drive.

\section{Analysis of recent research and publications}

The technique of transmitting torque through an elastic wheel is known [1]. When creating a model of the driving wheel rolling process, the author is invited to take into account that the wheel rim has a particularly high tangential elasticity. Thanks to this theory, it has been established that the car tire has considerable elasticity not only in the radial but also in the tangential directions, and therefore the transmission of tractive force significantly changes the rolling radius of the drive wheel.

To increase the efficiency of mobile energy facilities (MEF), great attention is paid to the problem of increasing the efficiency of wheel drives, which is provided by the Law of Ukraine "On the system of engineering and technical support of the agro-industrial complex of Ukraine" [2].

Researchers have developed the most complex and difficult application problem of rolling of an elastic wheel on soil, which is solved on the basis of preliminary choice of the curve formula, which corresponds to the longitudinal line of contact of interacting bodies [3]. In order to increase traction possibilities it is proposed to use the gravitational moment by introducing into the transmission of the tractor a gravitational thrower, equations for the force of support of the movement of the tractor are obtained. Theoretical calculations have established the factors of influence on the change of the geometry of the flexible bandage $[4,5]$.

In [6], the parameters of the angular load of the wheel propulsion and the equation of the speed of energy transfer to the wheel propulsion, depending on the speed of change of the torque, were revealed.

In studies on the quality of wheel propulsion [1, 2], little attention is paid to providing a given direction of movement in the appropriate operating conditions of cars and tractors. Substantial improvement of wheel propulsion is possible only on thorough theoretical and experimental researches. The urgency is to identify the factors that influence the stabilization of a given direction of movement of cars and tractors. Therefore, studies of the factors that influence the stabilization of their movement are relevant.

To increase the stability of a given direction of movement of tractors and cars at high speeds, it is suggested to take into account the horizontal jet moment. Operation of the traction power means that when its deviations are not programmed from a given direction of movement, each cross-section of its design returns relative to a predetermined direction of motion (axis $Z$ ) as a rigid bar, with the trajectory of motion is transformed into elements of the helical line BS.

\section{Objective}

To improve the technology of transferring energy from the engine to the wheel motors and to create a physico-mathematical model for the interaction of the deformed wheel drive with the deformed support surface.

\section{Presentation of basic material}

When rolling the wheel propulsion 1 (Fig. 1), point $K$ moves along the line of contact of the deformed part of the tire $A B$ with rigidity $c$. Assume that at point $K$ is the concentrated force of the weight of the operating mass $m$. To determine the dependence of the unstable position in the contact spot area of the application of the reaction of the reference surface in its relative motion along the contact line of the deformed tire with the reference surface of the angular velocity $\omega$ of the wheel propulsion 1 . To this end, construct the axes of the moving coordinate system starting at the point $O$, when propulsion 1 was stationary.

In determining the forces acting on the position of the point of application of the reference reaction in the zone $A B$ of the deformed part of the tire, a physico-mathematical model of Fig. 1. When rolling a wheel propulsion 1 , the reaction of applying a reference reaction to it will shift by the value of $\Delta x$. In this case, the part of the tire 2 that is sandwiched between point $A$ and point $O$ will be compressed, and the part of the tire that is released from the load when rolling the wheel drive, ie between points $O$ and $B$, will be released, that is, stretched. The force that will be contained in the

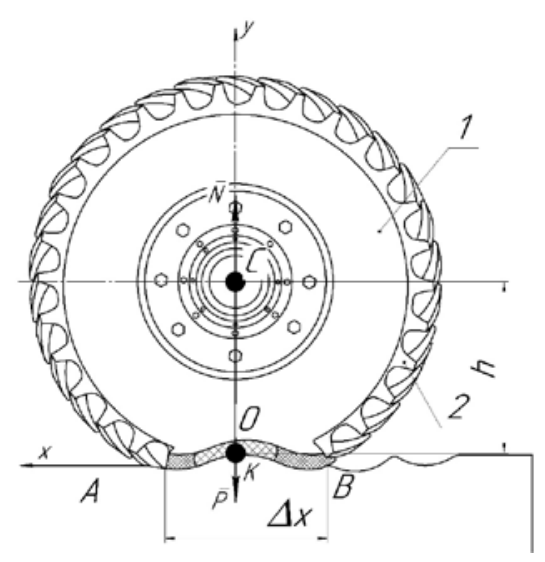

Fig. 1. Model of a wheel drive at rest 
compressed part of the tire and the extended part of the tire in accordance with the law of Hook will be proportional to their $\Delta x$ magnitude and directed to the cell of the deformed part, that is, to the point $O$.

Therefore, the reaction position of the support surface on the deformed part of the tire will be affected by the active force:

$$
F=-c \Delta x,
$$

where $\Delta x-$ the size of the deformed part of the tire.

In order to improve the accuracy of rolling wheel rolling calculation 1, we propose to detect the influence of Coriolis forces, $\Phi_{c}$ - portable and $\Phi_{o}$ - rotary on its deformed part of the tire.

Determine that the wheel propulsion is acted on by the transmissible inertia force, which is equal to the product of the operational weight $m$ for the portable acceleration of that wheel propulsion:

$$
F_{\text {por }}=m \omega^{2} r=m \omega^{2} \sqrt{h^{2}+(\Delta x)^{2}},
$$

where $h$ is the distance from the center of the wheel to the upper point of the deformed part of the tire.

The rolling of a wheel propulsion is influenced by the rotating Coriolis force, which is taken into account as the product of the weight on the wheel propulsion and Coriolis acceleration:

$$
F_{\text {rot }}=m \omega \dot{x} \text {. }
$$

The formula for determining the impact on the rolling motion of a wheel drive on a deformed part of the tire will be:

$$
m \ddot{x}=-c X+m \omega^{2} x+m \omega \dot{X} .
$$

The process of rolling the wheel drive on the support surface is impossible without friction of the tire on this surface. Such friction is caused by normal pressure on the deformed part of the tire. In turn, the effect of the normal pressure on the tire deformation is related to the effect on it of the turning force and the normal carrying force of inertia.

The turning power of Coriolis:

$$
\Phi_{c}=2 m \omega \Delta \dot{x},
$$

that occurs when rolling a deformed part of the tire varies in magnitude and direction. This force is directed perpendicular to the plane of the deformed part of the tire. When the compression zone decreases, this force becomes more important, and when the compression zone of the tire increases, this force becomes smaller, until its direction changes.

The friction force that occurs when rolling a wheel propulsion on a support surface is always directed against the relative velocity, so the friction force that arises under the action of the Coriolis rotational force pressure can be determined from the formula:

$$
F_{f f}=f m \omega \Delta \dot{x} \text {. }
$$

The normal component of the transfer force of inertia of the deformed part of the tire is constant in magnitude. To determine Coriolis' portable force is necessary:

$$
\Phi_{e}=m \omega^{2} \sqrt{h^{2}+\Delta x^{2}} \text {. }
$$

multiply by directional sinus:

$$
\sin \alpha=\frac{h}{\sqrt{h^{2}+(\Delta \dot{x})^{2}}} .
$$

Then the normal component of the endurance of inertia will be determined from the formula:

$$
F_{n}=m \omega^{2} h \text {. }
$$

The total effect on the Coriolis rotary force wheel and the Coriolis transfer force will be determined from the formula:

$$
m \Delta \ddot{x}=-\left(c-m \omega^{2}\right) \Delta x+f m\left(2 \omega \Delta \dot{x} \pm \omega^{2} h\right) .
$$

The sign "+" in formula (2) will correspond to the condition of the tire in the support surface, and the sign "-" will correspond to the condition of the compression zone of the tire.

The solution of equation (2) corresponds to the dynamics of motion of the point of application of the equivalent gravitational force from the operating mass, which accounts for the deformed part of the tire of the wheel drive. 
If the wheel drive suddenly crashes into the pit, that is, h will be " 0 " $(h=0)$, then we get viscous damping, which will depend on the speed of the car.

Suppose a physical system (a moving car) has one degree of freedom, with the motion of the car being accompanied by an accumulation of kinetic and potential energy. We choose as the generalized coordinate the angle $\varphi$ of rotation of the wheel 1, Fig. 1 from the balanced position (at equilibrium $\varphi=0$ and $\mathrm{SD}=S_{3}=0$ ); when moving the system (moving car), we state that we consider small oscillations, and also assume that the angle $\varphi$ is not large enough.

To mathematically describe the interaction of kinetic and potential energy of a moving MEF, we define the kinetic energy $T$ of a system (a moving car), which is equal to the sum of the kinetic energy of all bodies:

$$
T=T_{1}+T_{2}+T_{3} \text {. }
$$

As the wheels 1 and 2 rotate about the axes $O_{1}$ and $O_{2}$, and the loaded car 3 moves gradually, so formulas for describing kinetic energy will have the form:

when

$$
T_{1}=\frac{1}{2} J_{1} \omega_{1}^{2}, T_{2}=\frac{1}{2} J_{2} \omega_{2}^{2}, T_{3}=\frac{1}{2} m_{3} \omega_{3}^{2},
$$

$$
J_{1}=\frac{m_{1} R_{1}^{2}}{2}, J_{2}=\frac{m_{2} R_{2}^{2}}{2} .
$$

All velocities in $T_{1}, T_{2}$ i $T_{3}\left(\omega_{1}, \omega_{2}, \cup_{3}\right)$ are expressed by the generalized velocity $\varphi$. Fuse for everything, $\omega=\varphi_{1}$. In what follows, in an exactly equilibrium configuration $v B=v A$, that is, $\omega_{2} r_{2}=\omega_{1} R_{1}$.

Where from $\omega_{2}=\omega_{1} R_{1} / r_{2}$ and $v_{3}=\omega_{2} R_{2}=\omega_{1} R_{1} R_{2} / r_{2}$.

Finally, given that $R_{1}=R_{2}=R, r_{2}=0.5 R$, we obtain:

$$
\omega=\varphi_{1}, \omega_{2}=2 \dot{\varphi}, v_{3}=2 R \varphi \text {. }
$$

Substituting the value of equation (4), where $R_{1}=R_{2}=R$ and (5) in equation (3), we obtain from equality (2) $T=a_{0} \varphi / 2$, where:

$$
a_{0}=\left(0,5 m_{1}+2 m_{2}+4 m_{3}\right) R^{2} .
$$

The potential energy $\Pi$ of a system (a moving car) in mathematical form will be:

$$
\Pi=\frac{1}{2} c\left(\lambda_{\text {STAT }}+\lambda_{\text {DYN }}\right)^{2}+m_{3} g h_{C 3} .
$$

Fig. 2 shows the continuation of the wheel drive.

Fig. 3 shows the Coriolis-loaded wheel with the possibility of increasing its traction capacity or the emergence of a dangerous situation in its rolling.

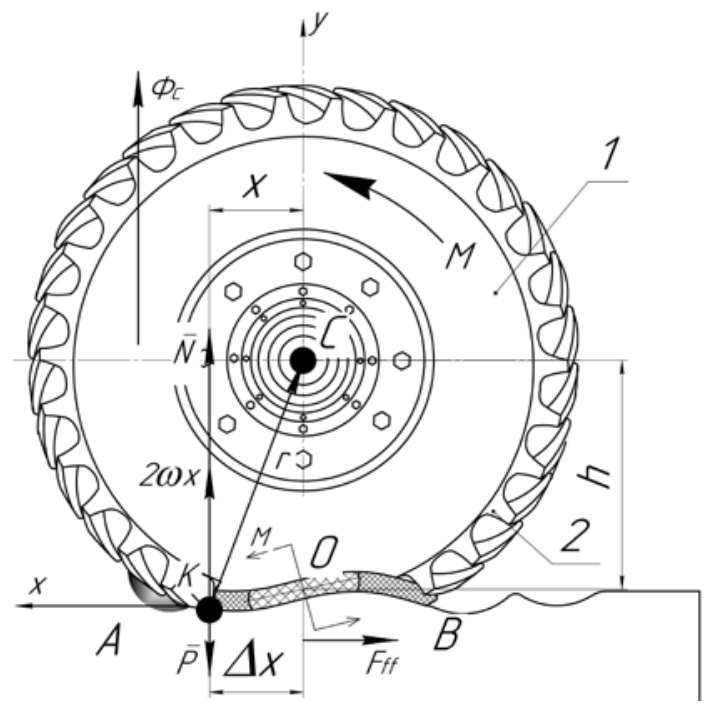

Fig. 2. Model of the wheel propulsion in the phase of beginning of movement

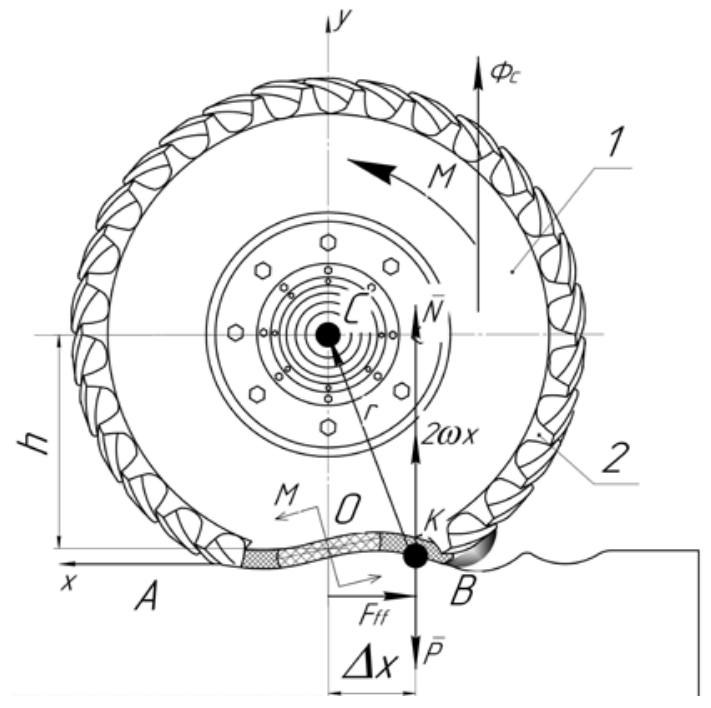

Fig. 3. Model of a wheel drive in the phase of Coriolis forces 


\section{Results}

The solution of equation (3) corresponds to the dynamics of motion of the point of application of the equivalent gravitational force from the operating mass, which is on the deformed part of the tire of the wheel drive.

If the wheel drive suddenly falls into the pit, that is, $h$ will be " 0 " $(h=0)$, then we obtain viscous damping, which will depend on the speed of the car, Fig. $4 a, b, c$.

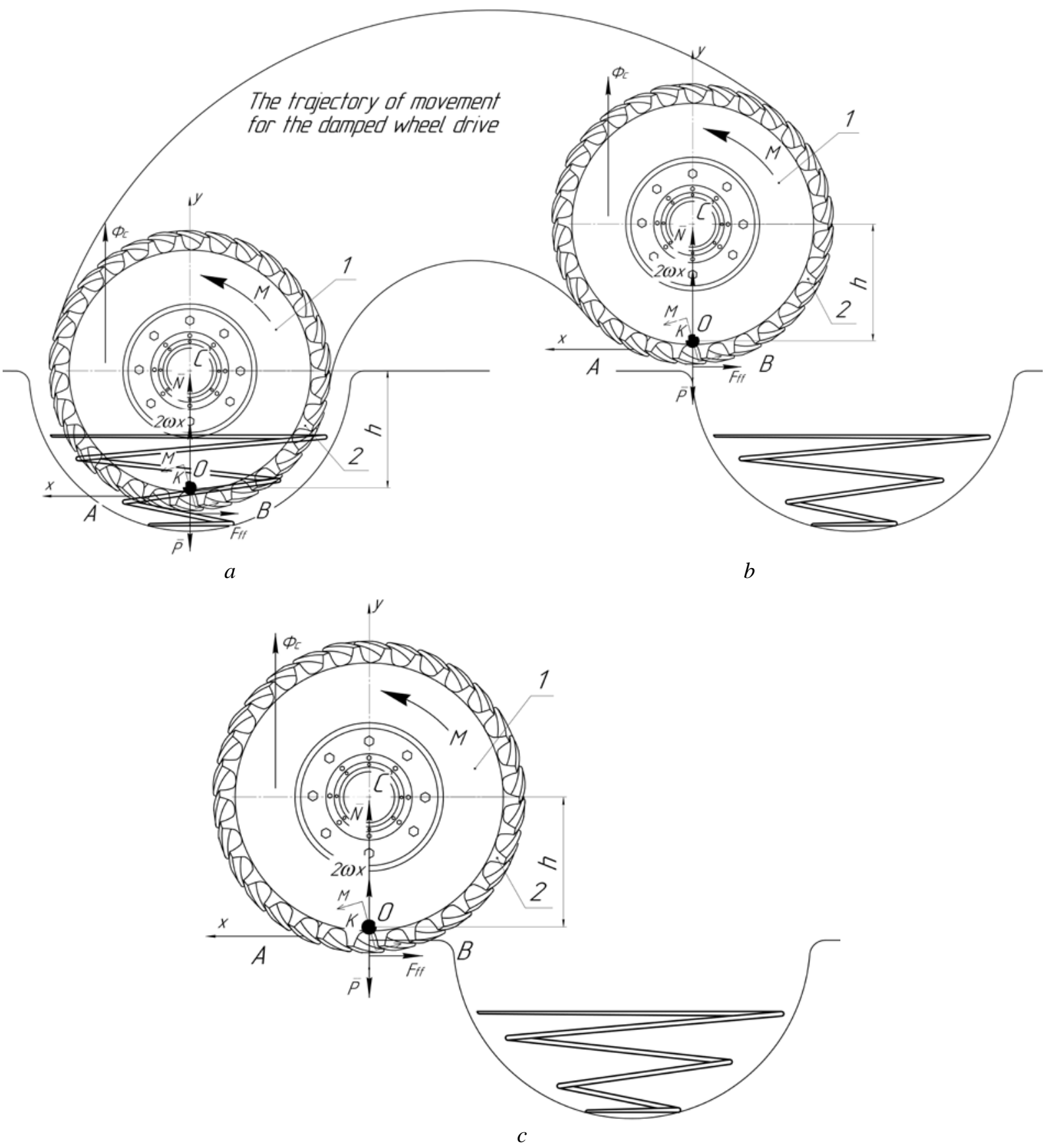

Fig. 4. Model of a wheel drive: in the pit (a); out of the pit in the bouncing phase (b); in the phase of pressing against the support surface (c) 


\section{Conclusions}

1. An overview of existing technologies for converting the energy of a wheeled vehicle into the work of moving a vehicle is given.

2. A physico-mathematical model of the process of rolling a wheel propulsion with Coriolis force is developed.

3. The geometry of the wheel drive in the cycle of damping of the failure of the support surface is developed.

4. The working process of rolling a wheel drive is a set of sequential processes: compression and stretching of the tire when it is deformed in the area of contact with the support surface.

5. Part of the duty cycle in the area of the contact area of the tire wheel drive with the support surface, periodically repeated depending on the speed of the wheel drive.

6. On the basis of the presented material was obtained the patent of technological direction "Method of movement of traction and transport system" test wheel drive.

In the future, the development of the problem will be aimed at improving the efficiency of the wheel drive by improving its design. The solution to the problem of Coriolis forces will allow designers to improve the design of the tread of a car wheel, which in turn will increase the reliability of the control of the traction vehicle, thereby increasing the likelihood of its safe movement.

\section{Література}

1. Киргоф Г.Р. Лекции по математической физике / под ред. А.Т. Григорьяна, Л.С. Полака. - пер. с 4-го нем. изд. Москва: КомКнига, 2014. 390 с.

2. Котович С.В. Движители специальных транспортных средств. Часть I: Учебное пособие. МАДИ (ГТУ). Москва, 2008. $161 \mathrm{c.}$

3. Черниш О.М., Березовий М.Г., Яременко В.В., Головач І.В. Теоретична механіка. Київ: Центр учбової літератури, 2018. $760 \mathrm{c}$.

4. Хусаинов А.Ш. Теория автомобиля. Конспект лекций / А.Ш. Хусаинов, В.В. Селифонов. Ульяновск: УлГТУ, 2008. 121 с.

5. Петров Л.М. Теорія колісного рушія з гнучким бандажем і динамікою навантаження гравітаційною складовою. Агр. вісник причорн. 2010. Вип. 55. С. 9-13.

6. Петров Л.М., Борисенко Т.М. Теорія транспортного засобу з елементами моделювання роботи колісного рушія довантаженого динамічною вагою. Вісті Автомобільно-дорожнього інституту: науково виробничий збірник. 2011. №1(12). С. $105-109$.

\section{References}

1. Kirgof, G.R. (2014). Lectures in mathematical physics. Moscow: ComBook.

2. Kotovich, S.V. (2008). Propulsion special vehicles. Part I, Moscow: MADI (GTU).

3. Chernish, O.M., Berezovy, M.G., Yaremenko, V.V., Golovach, I.V. (2018). Theoretical Mechanics. Kyiv: Center for Educational Literature.

4. Khusainov, A.Sh. (2008). Car theory. Lecture notes. Ulyanovsk: UISTU.

5. Petrov, L.M. (2010). Wheel propulsion theory with flexible bandage and loading dynamics of gravity component. Agrarian Bulletin of the Black Sea, 55, 9-13.

6. Petrov, L.M., Borisenko, T.M. (2011). The theory of a vehicle with elements of simulation of work of a wheel propulsion loaded with dynamic weight. Visti of the Automobile and Road Institute: scientific production collection, 1 (12), 105-109.

Петров Леонід Миколайович; Petrov Leonid, ORCID: https://orcid.org/0000-0001-5709-9986

Борисенко Тарас Миколайович; Borysenko Taras, ORCID: https://orcid.org/0000-0002-0557-7322

Received April 02, 2019

Accepted October 06, 2019 